\title{
Experimental versus theoretical study of reverse osmosis pilot scaling: The case of Algerian brackish water desalination
}

\author{
Abderrezak BOUCHAREB ${ }^{\mathrm{ABCEF} \otimes}$, Mehdi METAICHE ${ }^{\mathrm{DEF}}$, \\ Hakim LOUNICI $^{\text {DEF }}$
}

Bouira University, Faculty of Sciences and Applied Sciences, Department of Chemistry, 10000 Bouira, Algeria; e-mail: a.bouchareb@univ-bouira.dz,metiche022000@yahoo.fr, hakim_lounici@yahoo.ca

For citation: Bouchareb A., Metaiche M., Lounici H. 2019. Experimental versus theoretical study of reverse osmosis pilot scaling: The case of Algerian brackish water desalination. Journal of Water and Land Development. No. 42 (VII-IX) p. 49-58. DOI: $10.2478 /$ jwld-2019-0044.

\begin{abstract}
In recent years, the increasing threat to ground water quality due to human activities has become a matter of great concern. The ground water quality problems present today are caused by contamination and by over exploitation or by combination of both. Reverse osmosis (RO) desalination is one of the main technologies for producing fresh water from sea water and brackish ground water.

Algeria is one of the countries which suffer from the water shortage since many years, so desalination technology becomes inevitable solution to this matter.

In this study, a comparison is provided of results of reverse osmosis desalination for three different qualities of brackish water from the central-east region of Algeria (Bouira and Setif Prefectures), wherein they cannot use it as human drinking or in irrigation systems. The main objective of our study is to establish a comparison of the reverse osmosis membrane TW30-2540 performances in the term of (permeate flow, recovery rate, permeate total dissolved solids - TDS and salts rejection) under different operation pressures (each one takes a time of 720 second for pilot scaling). In order to make an overview comparison between the experimental and the simulated results we used ROSA (Reverse Osmosis System Analysis) software.

At the end of this study we noted that, the simulated results are lower than the pilot scaling values and the most removed salts are the sodium chlorides with $99.05 \%$ of rejection rate.
\end{abstract}

Key words: ions salts rejection, reverse osmosis (RO), ROSA software, salt passage (B), spiral wound membrane (SWM)

\section{INTRODUCTION}

According to the world population clock, the population exceeds 7 billion and will reach 10 billion by 2050 . Pure drinking water would be a major problem for the developing countries in the world. The improvement in the efficiency and cost of water treatment is a major challenge to overcome the scarcity of portable water [LALIA et al. 2013]. Due to multitude human activities from the industry to agriculture without forgotten the natural disasters; nowadays the demand of high quality ground water it became inevitable necessary, this to reduce the spread of epidemics as well as satisfying the popular needs. Declining resources of potable water are social and political as well as economic problem in many parts of the world. In addition, the requirements for the quality of the water are getting stricter and generally include wide range of needed analyses [MALCZEWSKA 2016].

There are 26 countries that do not have sufficient water resources to sustain agriculture and economic development, and approximately one billion people lack access to safe drinking water. Particular regions with water scarcity include a significant portion of the Middle East, North Africa, eastern Australia, parts of Central and South Asia, and 
the south-western areas of North America. In addition, the projected $40-50 \%$ growth in human population over the next 50 years, coupled with industrialization and urbanization, will result in an increasing demand on the available water resources. While economic use and recycling of water for human and animal consumption can mitigate the problem to some extent, alternative sources of clean water are required to address this growing need [ELKHARAZ et al. 2012].

Algeria is one of the countries in the world with water resources that are well below the threshold adopted by the World Bank. The situation is aggravated by the fact that there is a wrong spatial distribution of the water, seasonal and inter-annual irregularities of the rainfall, filling up of the reservoirs with sediment, vast losses of water due to the aging of the municipal distribution networks, bad management of the resources, pollution, insufficient infrastructure, and a lack of maintenance. The shortage of water affects both the drinking water supplies for the population and the supply of irrigation water for the farmers [World Bank 2004]; Algeria is one of the countries which they suffer from the water shortage since many years, so desalination technology became inevitable solution to this matter.

Desalination is used to separate salt from raw water for a different use specially in production of potable water, the process is carried out through distillation (evaporation, multi effect vapour compression) or membrane process such as reverse electro-dialysis reversal, nano-filtration and reverse osmosis (RO) [SUBRAMANI, PANDA 2014]. For the desalination of brackish water, RO is the method that is mainly used, as it is the most economic. Brackish water total dissolved solids $(T D S)$ which can vary from $2 \mathrm{~g} \cdot \mathrm{dm}^{-3}$ to approximately $10 \mathrm{~g} \cdot \mathrm{dm}^{-3}$, affects the cost of water produced in general ranges the range vary from 0.26 to 0.54 $\$ \cdot \mathrm{m}^{-3}$. When small units of $1000 \mathrm{~m}^{3} \cdot(24 \mathrm{~h})^{-1}$ cost can vary between 0.78 to $1.33 \$ \cdot \mathrm{m}^{-3}$.

Desalination systems can be divided in two categories: those which use a conventional source of energy and those powered by renewable energy sources (wind, solar, etc.); is well known that the cost of water produced from desalination systems using a conventional source of energy (gas, oil, electricity) is much lower that the systems with renewable energy sources. In Table 1 we show the different cost between brackish and seawater desalination in term of unit capacity and energy sources [KARAGIANNIS, SOLDATOS 2008]. From this table we noticed that the renewable energy source provide high desalination cost compared to a conventional and was limited only for small units.

Membrane process represent one of the most feasible option for water shortage alleviation and water supply augmentation such examples includes micro-filtration (MF) and ultra-filtration (UF) for membrane bioreactor in waste water treatment and pretreatment in sea water desalination as well as nano-filtration (NF) and reverse osmosis (RO) in brackish water and sea water desalination [BONGCHUL et al. 2014]. The membranes play a key role in membrane-based water treatment processes and determine the technological and economic efficiency of the aforementioned technologies; membrane improvement can greatly affect the performance of current technology.
Table 1.The different cost between brackish and seawater desalination in term of unit capacity and energy sources

\begin{tabular}{|l|c|c|l|c|}
\hline $\begin{array}{c}\text { Type of } \\
\text { feed water }\end{array}$ & $\begin{array}{c}\text { Size of plant } \\
\left(\mathrm{m}^{3} \cdot(24 \mathrm{~h})^{-1}\right)\end{array}$ & $\begin{array}{c}\text { Cost } \\
\left(€ \cdot \mathrm{m}^{-3}\right)\end{array}$ & $\begin{array}{c}\text { Type of energy } \\
\text { used }\end{array}$ & $\begin{array}{c}\text { Cost } \\
\left(€ \cdot \mathrm{m}^{-3}\right)\end{array}$ \\
\hline \multirow{3}{*}{$\begin{array}{l}\text { Brackish } \\
\text { water }\end{array}$} & $<1000$ & $0.63-1.06$ & conventional & $0.21-1.06$ \\
\cline { 2 - 5 } & $5000-6000$ & $0.21-0.43$ & photovoltaics & $4.50-10.32$ \\
\cline { 2 - 5 } & $\mathrm{nm}$ & $\mathrm{nm}$ & geothermal & 2.00 \\
\hline \multirow{4}{*}{ Sea water } & $<1000$ & $1.78-9.00$ & conventional & $0.35-2.07$ \\
\cline { 2 - 5 } & $1000-5000$ & $0.56-3.15$ & wind & $1.00-5.00$ \\
\cline { 2 - 5 } & $12000-60000$ & $0.35-1.30$ & photovoltaics & $3.14-9.00$ \\
\cline { 2 - 5 } & $<60000$ & $0.40-0.80$ & solar collectors & $3.50-8.00$ \\
\hline
\end{tabular}

Explanation: $\mathrm{nm}=$ not mention.

Source: own elaboration based on KARAGIANNIS and SOLDATOS [2008].

Reverse osmosis, is a well-known membrane technology for treatment of wastewater and production of potable or irrigation water; most industries, especially oil and gas refineries, utilize RO plants to provide highly purified water for various plants and equipment, such as reboilers [TAHERIFAR et al. 2015]. The RO membrane is a versatile method that has been widely adopted in water treatment applications such as desalination process is currently the undisputed leading method, this method has been established to be the most economical technology for the desalination of brackish and sea water. RO membranes are capable of rejection most ions and even mono-valent ion such as $\mathrm{Na}^{+}$and $\mathrm{Cl}^{-}$present in sea water with $99 \%$ rejection rate; the spiral wound membrane (SWM) module the basic component for building a very broad range of water treatment facilities, for sea- and brackish-water desalination as well as purification of assorted effluents for reuse. Have presented an illuminating account of technological developments and industrial requirements that have led to the dominance of SWM modules in desalination and water treatment applications by JOHNSON and BUSH [2010] and HCHAICHI et al. [2014].

A membrane envelope is made of two sheets, glued at the three edges, with a fabric filling the permeate channel. The open permeate-side of this envelope is fixed on a perforated inner tube where the permeate is collected. Several envelopes, separated by relatively thin net-type spacers, are tightly wrapped around the perforated inner tube. The morphology of commercial elements, including the recently developed large $(0.4064-0.4572 \mathrm{~m})$ elements, has remained essentially unchanged. Moreover, plans for even larger $(0.6096 \mathrm{~m})$ module, are apparently based on the same SWM morphology. During recent decades, very significant improvements in SWM performance were due to improved membrane surface characteristics by [ELIMELECHM, PHILLIP 2011; KURINAHARA, HANAKUWA 2013].

In the compact design of SWM modules, packing a large membrane surface area per unit volume leads to very narrow spacer-filled flow channels (of gap less than $1 \mathrm{~mm}$, which tend to aggravate operating problems, i.e. friction losses, membrane fouling and scaling. Moreover, this design poses serious challenges to investigators aiming to study in detail SWM module performance. Specifically, despite recent progress e.g. detailed/local non-invasive measurements inside real modules are almost impossible to make, thereby depriving investigators of essential information by [KARABELAS et al. 2015]. 
The purpose of this paper is to achieve a global comparison between reverse osmosis pilot scaling and software (ROSA - reverse osmosis system analysis) simulation results in the terms of (permeate flow, recovery rate, permeate TDS and salts rejection), in this context were used three different brackish water from the Central-East of Algeria (Bouira and Setif prefectures) in which they suffer from the high salinity of water quality as well as the water shortage, under a commercial membrane TW30-2540 which represents the inexpensive membrane module in the range of brackish water desalination, thus is available for all users.

During this study were worked with five different operation pressure each of them took a time of $720 \mathrm{~s}$, in order to study the effect of those pressures on the evolution of (permeate and feed) conductivity, permeate flow, recovery rate and ions salts rejection.

\section{METHODS AND MATERIALS}

\section{FEED WATER CHARACTERIZATION}

The feed water came from three different wells from inland region (Bouira and Setif prefectures) of Algeria. The characteristics of the feed water are given in Table 2 . It should be noted that all feed water took a conventional pretreatment before they passed by RO pilot, this pretreatment is based on chemical coagulant/flocculent the ferric chloride hexa-hydrate $\left(\mathrm{FeCl}_{3} \cdot 6 \mathrm{H}_{2} \mathrm{O}\right)$ and cationic polymer (bentonite) from Canada.

Table 2. Feed water characteristics

\begin{tabular}{|l|c|c|c|c|}
\hline \multicolumn{1}{|c|}{ Characteristic } & $\begin{array}{c}\text { Measurement } \\
\text { unit }\end{array}$ & $\begin{array}{c}\text { Well I } \\
\text { (Setif) }\end{array}$ & $\begin{array}{c}\text { Well II } \\
\text { (Bouira) }\end{array}$ & $\begin{array}{c}\text { Well III } \\
\text { (Bouira) }\end{array}$ \\
\hline $\mathrm{pH}$ & - & 7.75 & 6.95 & 7.05 \\
\hline Temperature & ${ }^{\circ} \mathrm{C}$ & 17.3 & 19 & 19 \\
\hline Conductivity & $\mathrm{mS} \cdot \mathrm{cm}^{-1}$ & 6.46 & 3.77 & 4.65 \\
\hline Calcium & $\mathrm{mg} \cdot \mathrm{dm}^{-3}$ & 560.88 & 228 & 280 \\
\hline Sodium & $\mathrm{mg} \cdot \mathrm{dm}^{-3}$ & 1360 & 680 & 1020 \\
\hline Magnesium & $\mathrm{mg} \cdot \mathrm{dm}^{-3}$ & 106.27 & 43.20 & 54.72 \\
\hline Potassium & $\mathrm{mg} \cdot \mathrm{dm}^{-3}$ & 1.42 & 15.90 & 2.10 \\
\hline Chloride & $\mathrm{mg} \cdot \mathrm{dm}^{-3}$ & 2680 & 1340 & 2000 \\
\hline Bicarbonate & $\mathrm{mg} \cdot \mathrm{dm}^{-3}$ & 549 & 427 & 219.6 \\
\hline Sulphate & $\mathrm{mg} \cdot \mathrm{dm}^{-3}$ & 85 & 85 & 98 \\
\hline Carbonate & $\mathrm{mg} \cdot \mathrm{dm}^{-3}$ & 0.53 & 0.33 & 1.66 \\
\hline
\end{tabular}

Source: own elaboration.

\section{REVERSE OSMOSIS MEMBRANE}

The cartridge type RO membrane used in this study was commercial membrane TW30-2540. The membranes are spiral wound modules each with a surface area of $2.6 \mathrm{~m}^{2}$ and allowing a permeate flow of $3.2 \mathrm{~m}^{3} \cdot(24 \mathrm{~h})^{-1}$ with a salt rejection of $99.5 \%$. The operating characteristics of the membrane are as follows in Table 3.

\section{REVERSE OSMOSIS PILOT}

A multi-cellular centrifugal pump high pressure $\left(16 \cdot 10^{5} \mathrm{~Pa}, 800 \mathrm{dm}^{3} \cdot \mathrm{h}^{-1}\right)$ feeds a circuit including a $\mathrm{RO}$
Table 3. Sheet TW30-2540 membrane characteristic

\begin{tabular}{|c|c|}
\hline Specification & Characteristic \\
\hline Membrane type & polyamide thin-film composite \\
\hline Maximum operating temperature $\mathrm{a}^{\mathrm{a}}$ & $113^{\circ} \mathrm{F}\left(45^{\circ} \mathrm{C}\right)$ \\
\hline Maximum operating pressure & 600 psig $\left(41 \cdot 10^{5} \mathrm{~Pa}\right)$ \\
\hline Maximum feed flow rate & $6 \mathrm{gpm}\left(1.4 \mathrm{~m}^{3} \cdot \mathrm{h}^{-1}\right)$ \\
\hline Maximum pressure drop & 13 psig $\left(0.9 \cdot 10^{5} \mathrm{~Pa}\right)$ \\
\hline $\mathrm{pH}$ range, continuous operation & $2-11$ \\
\hline $\mathrm{pH}$ range, short-term cleaning $(30 \mathrm{~min})^{\mathrm{b}}$ & $1-13$ \\
\hline Maximum feed silt density index & SDI 5 \\
\hline Free chlorine tolerance ${ }^{\mathrm{c}}<0.1$ & $10^{-3} \mathrm{~g} \cdot \mathrm{dm}^{-3}$ \\
\hline
\end{tabular}

Explanations: $\mathrm{a}=$ maximum temperature for continuous operation above $\mathrm{pH} 10$ is $95^{\circ} \mathrm{F}\left(35^{\circ} \mathrm{C}\right) ; \mathrm{b}=$ Refer to Cleaning Guidelines in specification sheet 609-23010; $\mathrm{c}=$ under certain conditions, the presence of free chlorine and other oxidizing agents will cause premature membrane failure. Source: Dow [undated].

cartridge. This circuit consists of a power supply, a discharge and permeate.

The tank containing the solution to be treated is 100 $\mathrm{dm}^{3}$ capacity; the drip tray has a capacity of $20 \mathrm{dm}^{3}$. They are both transparent PVC. The feed tank is filled via a filter $25 \cdot 10^{-6} \mathrm{~m}$ and an active carbon filter $\left(5 \cdot 10^{-6} \mathrm{~m}\right)$. The driver can thus operate independently from the input tray. The pump stops automatically when the low level of the tank is reached. In Figure 1 we show the principal layout of reverse osmosis pilot.



Fig. 1. Schematic diagram of reverse osmosis MP20 device; source: own elaboration

Lists instrumentation and controls included in the system are presented in Table 4.

Table 4. Pilot instrumentations

\begin{tabular}{|l|c|}
\hline \multicolumn{1}{|c|}{ Purpose } & Model number \\
\hline Pump & e-SV K 3 \\
\hline Flow & PDP/731 \\
\hline Pressure & D100-MEX5 \\
\hline Conductivity and temperature & M CLM 223 \\
\hline
\end{tabular}

Source: own elaboration. 


\section{PILOT CONFIGURATION}

\section{Single stage (continuous) reverse osmosis}

Most exiting RO systems operate in single-stage (or single-pass) configuration. In a single-stage RO, the feed solution concentration along the membrane channel increases as water permeates across the semi-permeable membrane under an applied hydraulic pressure that is higher than the local osmotic pressure (Fig. 2).



Fig. 2. Schematic representation of the single stage reverse osmosis process; $P_{F}=$ feed pressure, $Q_{F}=$ feed flow, $C_{F}=$ feed pressure, $Q_{B}=$ brine flow, $C_{r}=$ retentate concentration, $P_{o}=$ atmospheric pressure, $Q_{p}=$ permeate flow, $C_{p}=$ permeate concentration; source: own elaboration

\section{Batch reverse osmosis}

In a closed-circuit (batch-RO) process, the retentate (brine) solution of the module (stream $\mathrm{S}_{3}$ in Figure 3) recirculates in closed circuit where it mixes with the feed solution of the system $\left(\mathrm{S}_{1}\right)$ to become the influent solution to the module $\left(\mathrm{S}_{2}\right)$.

Here, the feed solution of the system $\left(\mathrm{S}_{1}\right)$ represents the source water to be desalinated, which has an osmotic pressure of $\pi_{0}$. The influent solution to the module $\left(\mathrm{S}_{2}\right)$, resulting from mixing the retentate solution $\left(\mathrm{S}_{3}\right)$ with the feed water $\left(\mathrm{S}_{1}\right)$, has an increasing osmotic pressure as the solutes accumulate in the circuit. To maintain a positive driving force across the membrane, the applied hydraulic pressure must be increased along with the increasing osmotic pressure.

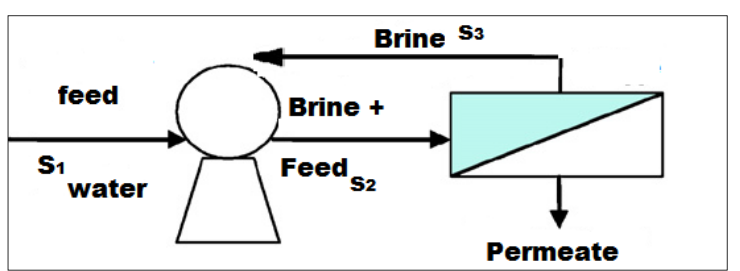

Fig. 3. Schematic representation of the batch reverse osmosis process; $S_{1}=$ feed stream, $S_{2}=$ mixture of (feed + brine) stream, $\mathrm{S}_{3}=$ permeate stream; source: own elaboration

\section{GOVERNING EQUATIONS}

The RO membrane model is developed based on the following basic assumptions [GERALDES et al. 2005; VAN DER MEER, VAN DIJK 1997]:

1) pressure drop along the permeate channel is neglected; this assumption is reasonable for $20.32 \mathrm{~cm}$. Spiral wound module that has 37 membrane leaves with a length of $1 \mathrm{~m}$;

2) the feed channels of spiral wound element are flat; feed stream flow along the channel parallel to the central line of the module and the curvature of membrane module was reported to have in-significant effect on system's performance; therefore, an un-wound flat sheet membrane with same channel height and spacers would adequately represent characteristics of the corresponding spiral wound RO module; water and salt fluxes via the membrane is estimated by Kimura-Sourirajan model.

Regarding to the main objective of this study we choose some theoretical simplifications based on the works of Bourouni [2012], Chapmane [2013], Dow [undated].

The water flow rate $Q_{p}$ product by RO membrane was calculated as Equation (1):

$$
Q_{p}=A \cdot S \cdot T C F \cdot F \cdot(\Delta P-\Delta \pi)
$$

Where: $A$ is the membrane pure water permeability, TCF is the temperature correction factor, $F$ is the membrane fouling factor $(0.8=F=1)$ in our case we suppose the $F=1$, $\Delta P$ is the applied trans-membrane pressure and $\Delta \pi$ is the trans-membrane osmotic pressure, $S$ membrane active surface $\left(\mathrm{m}^{2}\right)$.

The osmotic pressure in the different elements of RO unit is given by Equation (2):

$$
\pi=0.002654(T+273) C \frac{1}{1000-\frac{C}{1000}}
$$

Where $C$ is the salt concentration.

The temperature correction factor $T C F$ is established by the Dow [undated] as Equations (3) and (3'):

$$
\begin{aligned}
& T C F=\exp \left[2640\left(\left(\frac{1}{298}\right)-\left(\frac{1}{273+T}\right)\right)\right], T \leq 25^{\circ} \mathrm{C} \\
& T C F=\exp \left[3020\left(\left(\frac{1}{298}\right)-\left(\frac{1}{273+T}\right)\right)\right], T \geq 25^{\circ} \mathrm{C}
\end{aligned}
$$

The average pressure drop $\Delta P$ between the first and the last element is given by Equation 4:

$$
P=P_{f}-\frac{1}{2} P_{f s}
$$

$\Delta P_{f s}$ represents the pressure drop between feed and discharge of a single element, it's given as Equation (5):

$$
\Delta P_{f S}=0.01 Q_{f c}^{-1 / 7}
$$

The recovery rate $Y$ is given by Equation (6):

$$
Y=\frac{Q_{p}}{Q_{c}}
$$

The product concentration $C_{p}$ is function of recovery rate and salt rejection (Eq. 7); the Brine concentration $C_{c}$ of $\mathrm{RO}$ element is calculated from the Equation (8):

$$
\begin{gathered}
C_{p}=(1-Y) C_{f c} \cdot P_{f} \cdot T C F \frac{s}{Q_{p}} \\
Q_{f} \cdot C_{f}=Q_{p} \cdot C_{p}+Q_{c} \cdot C_{c}
\end{gathered}
$$

The cross flow velocity $V_{x}$ is estimated as Equation (9): 


$$
V_{x}=\frac{\left(Q_{f}+Q_{c}\right)}{2} A_{x}
$$

Where $A_{x}$ is the cross section area of the space between membrane envelopes in the modules calculated as the length of a module leaf (estimated at $1.016 \mathrm{~m}$ ) times the number of leaves times the spacer thickness.

The salts passage $B$ (dimensionless) is given by Equation (10):

$$
B=\frac{C_{p}}{\left[\left(\frac{C_{f}}{Y}\right) \ln \left(\frac{1}{1-Y}\right)\right]}
$$

We were using the Equation (11) to calculate the rejection ratio $R$ :

$$
R=1-\frac{C_{p}}{C_{f}}
$$

Concentration polarization $C P$ on membrane surface phenomenon may be described using the film theory [MiCHAELS 1968] as function of mass transfer coefficient:

$$
C P=\frac{C_{m}-C_{p}}{C_{b}-C_{p}}=\exp \left(\frac{J w}{k}\right)
$$

\section{ROSA SOFTWARE}

In this study we were used software namely (Reverse Osmosis System Analysis - ROSA), this software has a sophisticated design program that predicts the performance of membranes in user specified systems, in which has incorporates a model for both process RO/NF. The software has been used with success for the analysis of the performance of membranes, energy requirements and cost for desalination.

In most cases, optimization during the pilot phase is mostly based on the empirical method, involving the special know-how of the user. This also results in a lengthy period of process development.

The software allows virtual creation of the basic $\mathrm{RO} / \mathrm{NF}$ design with the choice of feed water composition, feed water flow rate, feed water pressure, temperature and $\mathrm{pH}$. Then, a configuration of the number of membranes, pressure vessels, type of membrane, feed and booster pumps is determined. The software has been used in many research papers for our case we using ROSA 9 by ELAZHAR et al. [2013].

In this paper were used a batch configuration for all our experiments for reason to give a better understanding to the phenomena in the term of (time process, trans-membrane pressure and recovery rate), in which were worked with five different operation pressures each one took $720 \mathrm{~s}$ for pilot scaling, after varying and registering the different parameters, in the next section were discussed the results based on the theoretical equations as well as the software (ROSA) values which will be taken as a reference.

\section{RESULTS AND DISCUSSION}

\section{CONDUCTIVITY REMOVAL}

As the principal objective of reverse osmosis desalination for both brackish and sea water is to remove the maximum hardness for get a water sample which satisfy the needs.

In our case and in this section were used three different brackish water to studied the evolution of (permeates and feeds) conductivity related to difference trans-membrane pressure during $3600 \mathrm{~s}$ of pilot scaling.

In order to pass to high pressure level each $720 \mathrm{~s}$, with the aid of Endress+Hauser instrument were registered the different values of (feeds and permeates conductivity) as presented in Figure 4.

According to this figure it is clear that the feed conductivity increased as the time passed beside the permeate conductivity which remains decreasing in each operation pressure.

As were mentioned above that in this study, were worked with batch process (as indicated in Fig. 3), for reason to get a good amount in permeate as well as sufficient time to understand the phenomena.

Under this process, the increase of feed conductivity was explained by the effect of the mixture (feed + brine) in the osmotic pressure values which are increased.

Generally, were confirmed that this membrane under those conditions, could be removed the maximum conductivity with a rate of $(97-98 \%)$.

\section{PILOT SCALING VERSUS ROSA SIMULATION}

In this section was presented the different evolutions which depend on the reverse osmosis theory and based on the experimental test (pilot scaling) and ROSA software simulation, were listed the different results in the Table 5.

\section{EFFECT OF THE OPERATION PRESSURE ON PERMEATES FLOW}

In this section were interested by comparing between the laboratory test (pilot scaling) and the software (ROSA) simulation, in which were presented the effect of the different operation pressure on the permeate flow, according to the RO theory (Eq. 1), the permeate flow increase simultaneously as operation pressure increased, as Figure 5 and Table 5 show, were noticed a constantly increase of the permeate flow followed by an increase in operation pressure for both (pilot scaling and ROSA simulation) values which in turn match with RO theory and confirm the previous equation (Eq. 1), knowing that were observed that the simulated results are lower than the experimental values; was explained this decline by the term of the fouling 

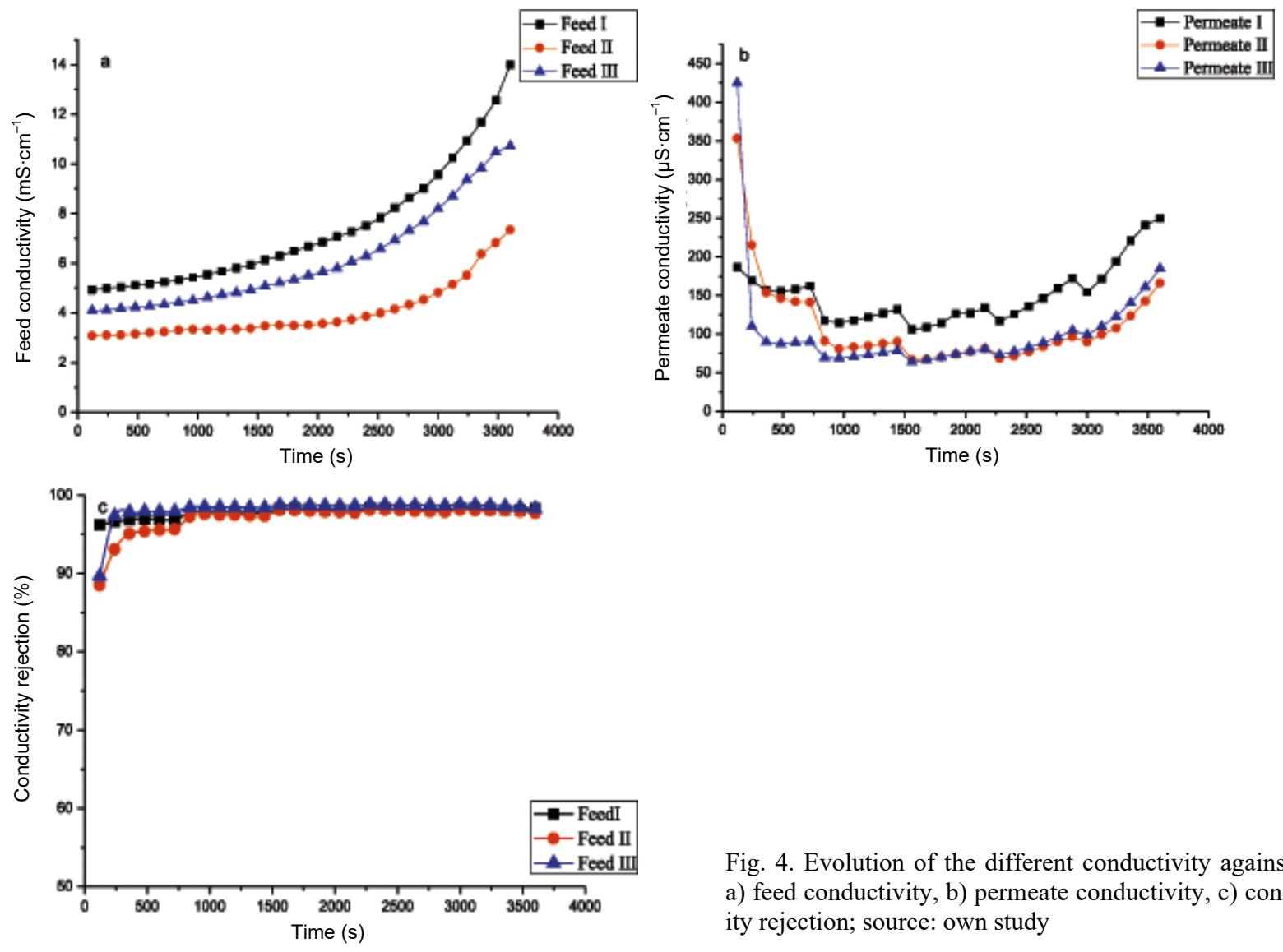

Fig. 4. Evolution of the different conductivity against time: a) feed conductivity, b) permeate conductivity, c) conductivity rejection; source: own study

Table 5. The evolution of different operation pressure $\Delta P$, permeate flow $Q_{p}$, recovery rate $Y$ and permeate $T D S$ between the pilot scaling and ROSA Software simulation results

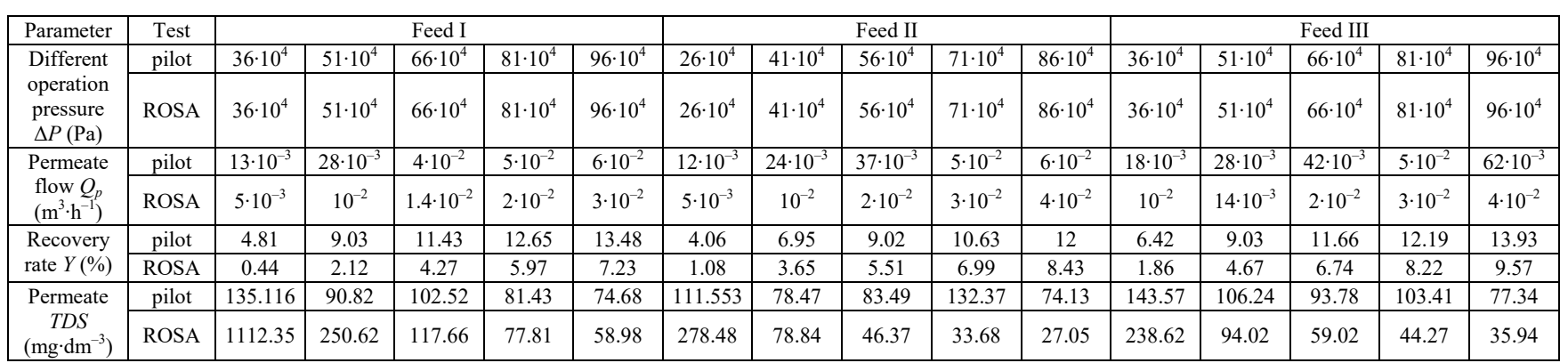

Source: own elaboration.

factor $(F)$ we take $F=0.85$ (standard value of ROSA) and the temperature correlation factor $(T C F)$ from Equations (3) and (3'), $\left(T_{\text {feed }}>25^{\circ} \mathrm{C}\right)$ the $(T C F>1)$ or $\left(T_{\text {feed }}<25^{\circ} \mathrm{C}\right)$ the $(T C F=1)$ in our case were worked with temperature lower than $25^{\circ} \mathrm{C}$ so $T C F$ it's always less than the unity; those values are the responsible for the decrease of permeate flow case of ROSA.

\section{EFFECT OF THE PERMEATE FLOW IN THE RECOVERY RATE}

From the RO theory background the evolution of the recovery rate against the permeate flow was managed by the two equations (Equations. 1 and 6), according to the Figure 6 and Table 5 were noticed the same evolution of the recovery rate against the permeate flow for all brackish water (recovery rate increase followed by increasing in the permeate flow) in which the recovery rate increase from $(4-15 \%)$ as the operations pressure varying from $\left(4.10^{5}\right.$ to $\left.10^{6} \mathrm{~Pa}\right)$ that explain by the pilot characteristic (1 pass per 1 stage).

As the ROSA software characteristic (doesn't take into account batch process) and their values were managed by the correlation factors (fouling and temperature) we observed diminution in their results compared with the pilot scaling values.

\section{EFFECT OF THE RECOVERY RATE IN THE PERMEATE QUALITY}

The term who specifies the permeate quality is known as TDS, in our case the initial TDS for our feeds water was measured as $3.852,2.262,2.790 \mathrm{~g} \cdot \mathrm{dm}^{-3}$ which represent a completely brackish water. 

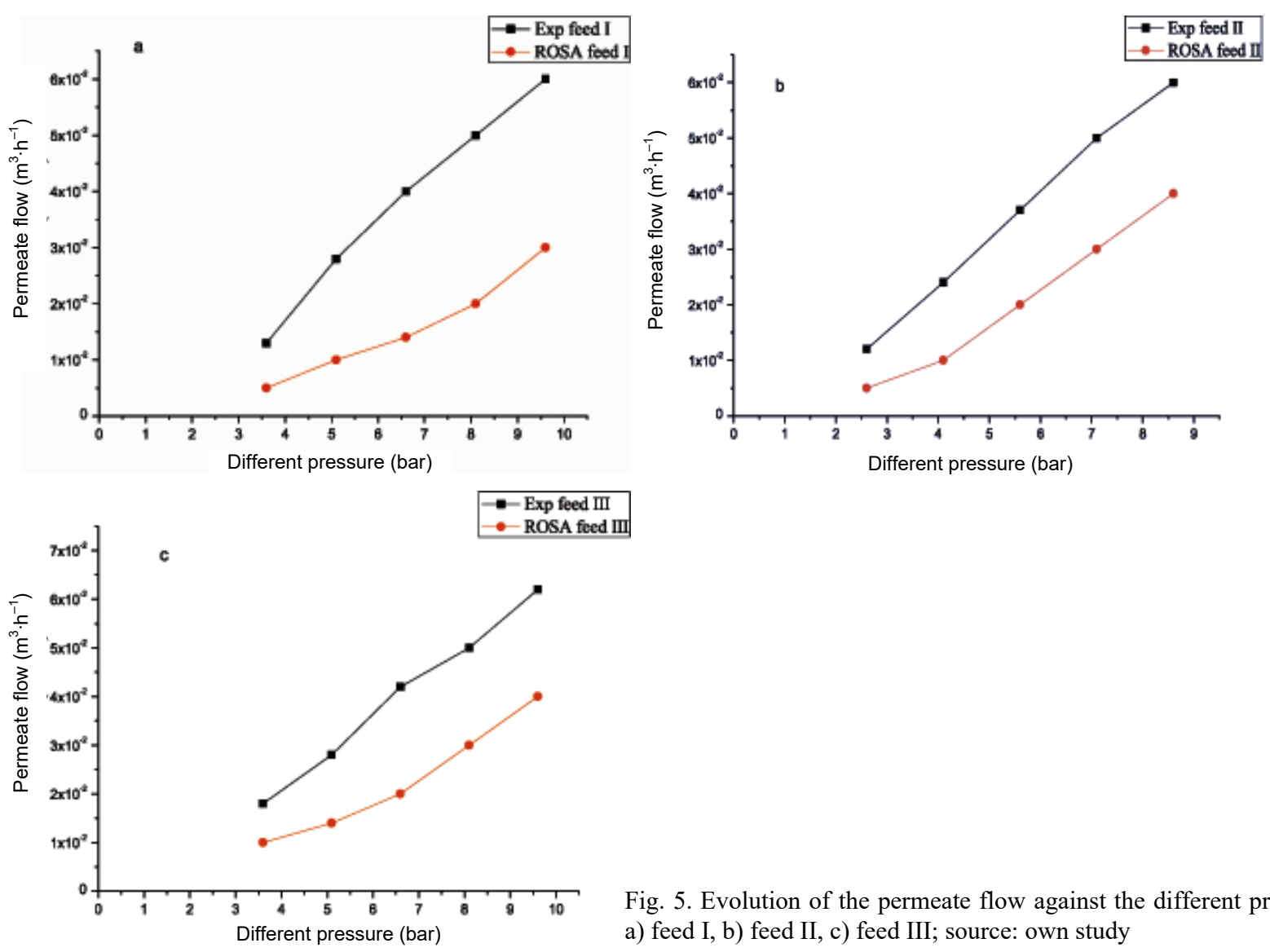

Fig. 5. Evolution of the permeate flow against the different pressure: a) feed I, b) feed II, c) feed III; source: own study


Fig. 6. Evolutions of recovery rate against permeate flow: a) feed I, b) feed II, c) feed III; source: own study 



In this section were represented the effect of recovery rate on the permeate quality.

According to the RO theory and based on the Equations (1), (6) and (7), was noted that the increasing values of the recovery rate followed by decline in permeate $T D S$ values.

As Table 5 and Figure 7 shown for both (pilot scaling and ROSA simulation values) increasing in recovery rate value followed by decline in TDS value which satisfied the RO theory background.

As was indicated above that, in this study we were choosing batch process for our experiment, for this were observed slightly increase in the scaling values, due to the instantaneous increase of osmotic pressure.

\section{THE SALTS PASSAGE (B)}

As were calculated the water and the salts permeability for a specific membrane TW30-2540 were found that water permeability $A_{W}=8.31 \cdot 10^{-12} \mathrm{~m} \cdot \mathrm{s}^{-1} \cdot \mathrm{Pa}^{-1}$ and the salts permeability $B=4.19 \cdot 10^{-12} \mathrm{~m} \cdot \mathrm{s}^{-1} \cdot \mathrm{Pa}^{-1}$.

With the aid of ionic analysis, in this section were interested about ions salt passage during $\mathrm{RO}$ operation as we shown in Figure 8.

Equation (10) indicated that the salts passage is directly related to the recovery variation. According to figure 8 were observed that all ions are restricted in the range of [0-0.35].

Regarding to the ions who formed the major salt in water (sodium $\mathrm{Na}^{+}$and chloride $\mathrm{Cl}^{-}$) they restricted in the range of [0-0.05], which correspond to the most restricted

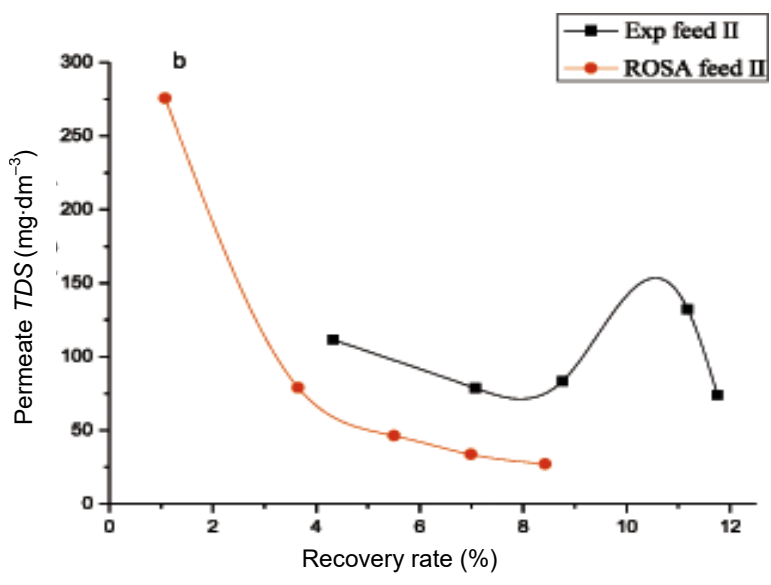

Fig. 7. The permeate total dissolved solids (TDS) against the recovery rate: a) feed I, b) feed II, c) feed III; source: own study

ions compared to potassium $\left(\mathrm{K}^{+}\right)$and sulphate $\left(\mathrm{SO}_{4}{ }^{2-}\right)$ who correspond the most ions penetrate with range of [0.15$0.35]$.

According to this were confirmed that the RO membrane is more effective with the mono ions such as $\left(\mathrm{Na}^{+}\right)$ and $\left(\mathrm{Cl}^{-}\right)$.

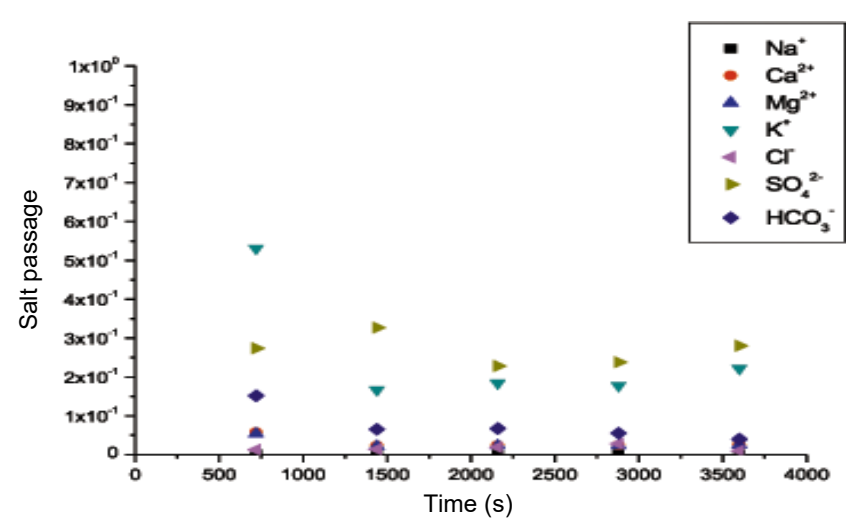

Fig. 8. Salts passage evolution during RO operation for each ions salts; source: own study

\section{A TW30-2540 PERFORMANCE IN IONS SALTS REJECTION}

As the manufacturer file for brackish water RO membrane (TW30-2540) the rejection ratio for $\mathrm{NaCl}$ salt is about $99.5 \%$, according to RO theory (Eq. 11), in this section were measured the rejection ratio for each ions salts, as were illustrated in Figure 9. The ions are ordered ac- 

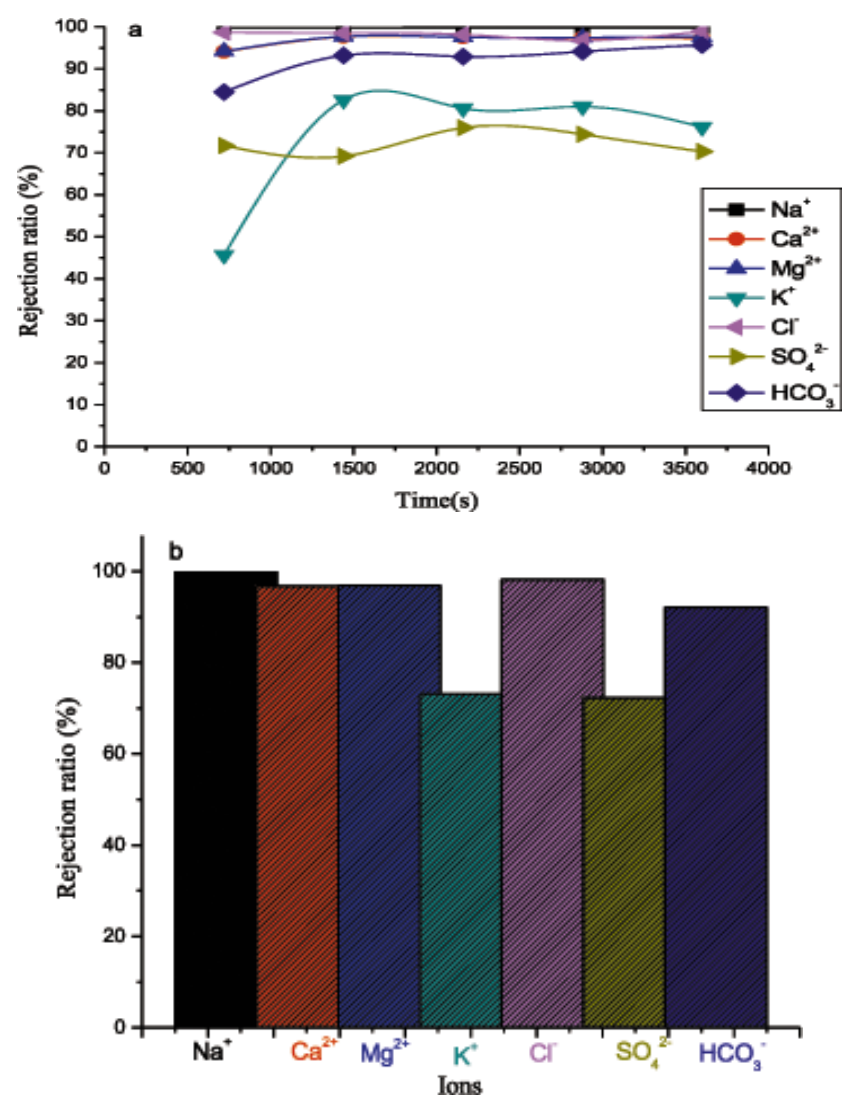

Fig. 9. Evolution of each ions rejection: a) during operation time, b) final rejection rate of each ions; source: own study

cording to their rejection rate value as: sodium $>$ chloride $>$ magnesium $>$ calcium $>$ bicarbonate $>$ potassium $>$ sulphate.

The low rejection value for the case of potassium, despite being among the mono ions, was explained by the low initial concentration and the competition at the membrane surface.

According to those results presenting above, which represented a comparative study between the experimental and simulated results in terms of brackish water reverse osmosis desalination, and based on the reverse osmosis theory background, we provide our discussion as follow:

- the preliminary step to determinate the reverse osmosis membrane performance it based on the conductivity removed as were noted above, TW30-2540 had maximum rate for all feed water we took was $98 \%$ when the operation pressure attain the $9 \cdot 10^{5} \mathrm{~Pa}$;

- in this phase the majority of ions exist in water are retracted by the membrane, according to the solutiondiffusion mechanism case of reverse osmosis membrane;

- in spite of that this study will remain insufficient to determine the membrane performance, which implies to add new factors who specified by the rejection of each ion salts in term of his permeability;

- it well known that the water is composed of several salts depend on their ions (mono-ions as well as di-ions) with a various fractions;

- in this work were chosen seven ions (four cation and three anion), as were showed above the maximum ions rejected by this membrane are the sodium and the chloride thus responsible of the major salt in water (sodium chloride) compared with di-ions which they had the high diffusivity (minimum rejection rate);

- according to this we confirmed that the RO membranes are more efficiency on the mono-ions than the others).

As were mentioned in the aim of this study, we provide a comparison between the simulated and the experimental results based on ROSA software and RO pilot scaling.

In this section we took the evolution of three factors (operation pressure on the permeate flow, the permeate flow on the recovery rate and the recovery rate on the permeate quality).

Based on the RO theory and the configuration choose in this study (batch process), were observed in despite of the same evolution between the experimental and the simulated results for all factors, were should be noted that we have a gap on values between them, which explain by the deficient of ROSA Software in case of batch process, real water sample and multivariate condition.

\section{CONCLUSIONS}

After making this comparison between the pilot scaling and ROSA software simulation, were ended this study by those remarks:

- for ROSA software were noticed that we could not figurate all the process (case of batch process) only the single stage configuration which could process it;

- their results was lower than the realistic (case of pilot scaling results) due to the correlations factors (fouling and temperature) in despite were had the same evolution between those results and pilot scaling results;

- about ions salts passage for the TW30-2540 membrane we found that sodium and the chloride are the most removed against the sulphate and the potassium which are the most diffuse, as the reverse osmosis principal (removing mono salts);

- for the rejection salt, we have a value of $99.05 \%$ for the $\mathrm{NaCl}$ salt compared with the manufacturer value.

\section{REFERENCES}

Bongchul K., Sangyoup L., Seungkwan H. 2014. A novel analysis of reverse draw and feed solute fluxes in forward osmosis membrane process. Desalination. Vol. 352 p. 128 135 .

BOUROUNI K. 2012. Optimization of renewable energy systems: The case of desalination. Modeling and Optimization of Renewable Energy Systems. Vol. 298 p. 90-116.

ChAPMANE M. 2013. Evaluation of high productivity brackish desalination membrane. Desalination. Vol. 308 p. 41-46.

Dow undated. DOW FILMTEC ${ }^{\text {TM }}$ Membranes. DOW FILMTEC tape-wrapped 2540 elements for commercial applications. Product data sheet. Dow Chemical Company pp. 3.

Dow undated. DOW FILMTEC ${ }^{\mathrm{TM}}$ MEMBRANES. Dow Water and Process Solutions. Technical Manual. Dow Chemical Company pp. 181.

Elazhar F., Elharrak N., ElazharM., Hafsi M., Elmidaoui A. 2013. Feasibility of nanofiltration process in dual stage in 
desalination of the seawater. Journal of Applied Chemistry IOSR. Vol. 5 p. 35-42.

Elimelechm M., PhilliP W.A. 2011. The future of sea water desalination: Energy, technology and environment. Science. Vol. 333 p. 712-717.

Elkharaz J., ElsadeK A., Ghaffour N., Mino E. 2012. Water scarcity and drought in WANA contries. Procedia Engineering. Vol. 33 p. 14-29.

Geraldes V., Pereira N.E., DePinho M.N. 2005. Simulation and optimization of medium-sized seawater reverse osmosis processes with spiral-wound modules. Industrial and Engineering Chemistry Research. Vol. 44 p. 1897-1905.

Hchaichi H., Siwar S., Elfil H., HanNachi A. 2014. Scaling prediction in sea water reverse osmosis desalination. Membrane Water Treatment. Vol. 5 p. 221-233. DOI 10.12989/ mwt.2014.5.3.221.

JOHNSON J., BUSH M. 2010. Engineering aspect of reverse osmosis module design. Desalination and Water Treatment. Vol. 15 p. 236-248.

KARAGiannis I.C., Soldatos P.G. 2008. Water desalination cost literature: Review and assessment. Desalination. Vol. 22 p. $448-456$.

Karabelas A.J., Kostologou M., Koutsou C.P. 2015. Modeling of spiral wound membrane desalination modules and plants-review and research priorities. Desalination. Vol. 356 p. $165-185$.

Kurihara M., Hanakawa M. 2013. Mega-Ton Water System: Japanese National research and development project on sea water desalination and west water reclamation. Desalination. Vol. 308 p. 131-137.

Lalia B.S., Kochkodan V., Hashaikeh R., Hilal N. 2013. A review on membrane fabrication: Structure, properties and performance relationship. Desalination. Vol. 326 p. 77-95.

MALCZEWSKA B. 2016. Evaluation of effectiveness of natural organic compounds removal from water in hybrid processes. Journal of Water and Land Development. Vol. 30 (VII-IX) p. 81-85. DOI 10.1515/jwld-2016-0024.

Michaels A.S. 1968. New separation technique for the chemical process industries. Chemical Engineering Progress. Vol. 64 p. $31-43$.

SubRAmANi S., PANDA R.C. 2014. Statistical regression and modeling analysis for reverse osmosis desalination process. Desalination. Vol. 351 p. 120-147.

Taherifar H., Rezvantalab S., Bahadori F., SAdrwadek KHOEI O. 2015. Treatments of reverse osmosis concentrate using natural zeolites. Journal of Water and Land Development. No. 25 (IV-VI) p. 41-46. DOI 10.1515/jwld-20150012.

VAN DER MEER W.G.J., VAN DIJK J.C. 1997. Theoretical optimization of spiral-wound and capillary nanofiltration modules. Desalination. Vol. 113 p. 129-146.

World Bank 2004. Seawater and brackish water desalination in the Middle East, North Africa and Central Asia: A review of key issues and experience in six countries. Vol. 2. Annex $1-$ Algeria pp. 38 [online]. [Access 10.10.2018]. Available at: http://documents.worldbank.org/curated/en/42116146819192 7352/Annex-1-Algeria

\section{Abderrezak BOUCHAREB, Mehdi METAICHE, Hakim LOUNICI}

\section{Eksperymentalne i teoretyczne badania odwróconej osmozy: Przykład odsalania słonawych wód Algierii}

\section{STRESZCZENIE}

Rosnące zagrożenie dla jakości wód podziemnych w związku z działalnością człowieka rodzi w ostatnich latach poważne obawy. Obecne problemy z jakością wód gruntowych są spowodowane zanieczyszczeniem i nadmierną eksploatacją albo obiema przyczynami łącznie. Odsalanie metodą odwróconej osmozy jest jedną z głównych technologii, mających na celu produkcję wody słodkiej z wody morskiej lub ze słonawych wód podziemnych.

Algieria jest jednym z krajów, które od wielu lat cierpią na niedostatek wody. Odsalanie jest więc nieuniknionym rozwiązaniem.

Przedstawione badania ukazują porównanie wyników odsalania trzech wód słonawych o różnej jakości pochodzących ze środkowowschodniego regionu Algierii (prefektury Bouira i Setif), gdzie wód tych nie można stosować ani do zaopatrzenia ludności, ani do nawodnień. Głównym celem badań było porównanie działania membrany TW30-2540 mierzonego przepływem, tempem odzysku, przepuszczalnością rozpuszczonych soli i usuwaniem soli w warunkach stosowania różnego ciśnienia (w pilotowym teście każdy wariant trwał 720 s). Do porównania wyników eksperymentalnych i symulowanych użyto programu ROSA (Reverse Osmosis System Analysis).

Wartości symulowane były mniejsze niż eksperymentalne wyniki testu pilotażowego, większość usuwanych soli stanowił chlorek sodu. Efektywność jego usuwania wyniosła 99,05\%.

Słowa kluczowe: membrana spiralna, odwrócona osmoza, program ROSA, stężenie soli, usuwanie soli 